\title{
Pengembangan Game Edukasi Menggunakan Software Construct 2 Berbantuan Phet Simulation Berorientasi pada Kemampuan Berpikir Kreatif Siswa
}

\author{
Debby Arisandy ${ }^{1}$, Jefri Marzal ${ }^{2}$, Maison ${ }^{3}$ \\ 1, 2, 3 Program Studi Pendidikan Matematika, Fakultas Keguruan dan Ilmu Pendidikan, Universitas Jambi, \\ Jl. Raden Mattaher No. 16-Jambi, Kota Jambi, Indonesia \\ debbyarisandy@gmail.com
}

\begin{abstract}
Creative thinking skills is one of the goals to be achieved from learning mathematics. However, students' creative thinking skills are currently still low. One way that can be done to improve creative thinking skills is to provide interesting learning media for students. In addition, the expected learning media is learning media that is easily accessible by students. Currently, most students use smartphones and are very skilled in using them. This is the background for the development of educational games using Software Construct 2 assisted by Phet Simulation as a learning medium aimed at facilitating students to improve their creative thinking skills. The research conducted is research and development using the ADDIE model. Instruments are divided into instruments of validity, practicality, and effectiveness. The research subjects were students of SMPN 8 Muaro Jambi. The results of the validity are obtained that the learning media developed has been declared valid by the validator through several revisions. The criteria for validity include content validity, namely the suitability of the components that underlie the manufacture of the product, and construct validity, namely the linkage of all components in product development. The learning media developed are also easy and can be used by teachers and students so that it can be concluded that the resulting product has also been declared practical and effective in improving students' creative thinking skills.
\end{abstract}

Keywords: Learning Media, Mathematics, Educational Games, Software Construct 2, Phet Simulation

\begin{abstract}
Abstrak
Kemampuan berpikir kreatif adalah salah satu tujuan yang ingin dicapai dari pembelajaran matematika. Namun kemampuan berpikir kreatif siswa saat ini masih rendah. Salah satu cara yang dapat dilakukan untuk meningkatkan kemampuan berpikir kreatif yaitu menyediakan media pembelajaran yang menarik bagi siswa. Selain itu media pembelajaran yang diharapkan adalah media pembelajaran yang mudah diakses oleh siswa. Saat ini sebagian besar siswa menggunakan Smartphone dan sudah sangat ahli dalam menggunakannya. Hal tersebut yang menjadi latar belakang dikembangkannya Game Edukasi menggunakan Software Construct 2 berbantuan Phet Simulation sebagai media pembelajaran yang ditujukan untuk memfasilitasi siswa meningkatkan kemampuan berpikir kreatif. Penelitian yang dilakukan adalah penelitian dan pengembangan dengan menggunakan model ADDIE. Instrumen dibagi menjadi instrumen kevalidan, kepraktisan, dan keefektivan. Subjek penelitian adalah siswa SMPN 8 Muaro Jambi. Hasil validitas diperoleh bahwa media pembelajaran yang dikembangkan sudah dinyatakan valid oleh validator melalui beberapa revisi. Kriteria kevalidan mencakup validitas isi yaitu kesesuaian komponen-komponen yang melandasi pembuatan produk, dan validitas konstruk yaitu keterkaitan seluruh komponen dalam pengembangan produk. Media pembelajaran yang dikembangkan juga mudah dan dapat digunakan oleh guru dan siswa sehingga dapat disimpulkan Produk yang dihasilkan juga sudah dinyatakan praktis yangmana, serta efektif meningkatkan kemampuan berpikir kreatif peserta didik.
\end{abstract}

Kata kunci: Media Pembelajaran, Matematika, Game Edukasi, Software Construct 2, Phet Simulation

Copyright (c) 2021 Debby Arisandy, Jefri Marzal, Maison

$\triangle$ Corresponding author: Debby Arisandy

Email Address: debbyarisandi@gmail.com (Jl. Raden Mattaher No. 16-Jambi, Kota Jambi, Indonesia)

Received 15 Agustus 2021, Accepted 24 September 2021, Published 25 September 2021

\section{PENDAHULUAN}

Kreativitas dalam menyelesaikan permasalahan matematika merupakan keterampilan yang dibutuhkan manusia untuk menghadapi perkembangan IPTEKS, tuntutan masyarakat, dan persaingan global yang semakin pesat (Hanipah, N., Yuliani, A., \& Maya, 2018). Namun, fakta menunjukkan bahwa kemampuan berfikir kreatif siswa pada pembelajaran matematika masih sangat rendah. Hasil 
Pengembangan Game Edukasi Menggunakan Software Construct 2 Berbantuan Phet Simulation Berorientasi pada Kemampuan Berpikir Kreatif Siswa, Debby Arisandy, Jefri Marzal, Maison

penelitian yang dilakukan oleh (Prastiti, T. D., Tresnaningsih, S., \& Mairing, (2018) di SMAN yang terakreditasi A di Surabaya menunjukkan bahwa sebanyak 5,4\% siswa terkategori sangat kreatif; 8,6\% siswa terkategori kreatif; 5,9\% siswa terkategori cukup kreatif; 67,7\% siswa terkategori kurang kreatif, dan $12,4 \%$ siswa terkategori tidak kreatif. Kesimpulannya, siswa yang terkategori kurang kreatif dan tidak kreatif adalah sebesar $80,1 \%$. Kondisi tersebut sangat memprihatinkan karena kebanyakan siswa tidak berani mengembangkan kreativitas yang ada dalam dirinya dan hanya perpaku pada rumus yang diberikan.

Penelitian lain juga dilakukan oleh Supardi (2015) yang menjukkan bahwa siswa tidak terbiasa berpikir, bersikap, dan berprilaku kreatif dalam proses pembelajaran karena tidak adanya stimulus yang diberikan guru untuk merangsang hal tersebut. Ini juga diperkuat dengan hasil PISA tahun 2018 (Kemendikbud, 2019)yang menunjukkan bahwa Indonesia memperoleh skor 371 untuk kemampuan membaca, 379 untuk kemampuan metematika, dan 389 untuk kemampuan sains. Dengan kata lain, hasil PISA Indonesia selalu berada di posisi bawah sejak pertama kali Indonesia mengikuti PISA, yaitu tahun 2000.

Rendahnya tingkat berfikir berfikir kreatif siswa ini, tentunya tidak lepas dari strategi dan media pembelajaran yang biasa diterapkan guru dalam proses pembelajaran di kelas. Jika para siswa berada pada ruang kelas dimana guru hanya memberikan penyajian materi yang monoton dan kegiatan pembelajaran yang selalu berulang, maka otak siswa tersebut akan berada pada situasi yang bisa mereka ramalkan. Siswa akan terbiasa menyelesaikan permasalahan matematika dengan rumus-rumus yang biasa pula guru berikan. Sehingga tidak ada kreativitas, tidak ada tantangan, terlihat sulit, dan membosankan.

Inilah yang menjadi pemicu bagi guru matematika untuk terus berinovasi dalam melakukan perubahan di lingkungan pendidikan. Pada zaman sekarang ini, teknologi dibutuhkan untuk membuat media pembelajaran matematika yang mampu mengembangkan kemampuan berfikir kreatif. Menurut Supardi (2018) proses kreatif itu akan muncul bila ada stimulus. Stimulus disini maksudnya adalah memberikan tantangan kepada siswa untuk menyelesaikan permasalahan matematika, sehingga akan timbul motivasi dari dalam dirinya.

Salah satu media pembelajaran yang dapat mengembangkan kemampuan berfikir kreatif siswa tersebut adalah PhET Simulation. PhET Simulation ini dapat membuat sesuatu yang terlihat abstrak menjadi lebih nyata melalui representasi gerakan objek. Menurut Sylviani, S., Permana, F. C., \& Utomo (2020) PhET Simulation menyediakan simulasi-simulasi komputer interaktif matematika dan sains berbasis penelitian yang interaktif, menyenangkan dan gratis yang dapat digunakan untuk meningkatkan keefektifan pengajaran dan pembelajaran matematika. Tujuan dari PhET Simulation adalah menyediakan media terbuka yang dapat digunakan oleh para siswa untuk bereksplorasi pada saat mempelajari konsep-konsep tertentu.

Pembelajaran berbasis eksplorasi ini sangat tepat diterapkan pada materi Bilangan di kelas VII SMP. Materi Bilangan adalah materi yang fundamental dan berkesinambungan karena konsep yang satu 
dengan konsep yang lain saling berhubungan. Materi Bilangan merupakan dasar dan prasyarat bagi pemahaman konsep selanjutnya yang lebih tinggi. Misalnya, siswa memahami penjumlahan merupakan prasyarat bagi pemahaman konsep perkalian, konsep Bilangan berpangkat, bentuk akar, dan lainnya.

Namun, materi tersebut merupakan pelajaran yang dianggap sulit bagi para siswa. Jika pada materi prasyarat, pemahaman konsep siswa kurang dan mengalami miskonsepsi, maka siswa mungkin akan kesulitan dalam menyelesaikan soal - soal matematika dan kesulitan pada materi - materi pengembangan selanjutnya. Menurut Utami (2016) adapun kesulitan-kesulitan yang dihadapi siswa pada meteri Bilangan yaitu: a) Pemahaman siswa terhadap konsep operasi hitung campuran Bilangan bulat dan pecahan masih kurang; b) Pemahaman siswa dalam prinsip membedakan antara jumlah kuadrat dan kuadrat jumlah masih kurang; c) Siswa lupa dengan rumus-rumus yang digunakan serta syarat-syarat penyelesaian operasi hitung Bilangan pecahan; d) Pemahaman siswa dalam mengkonversi prinsip pecahan campuran ke pecahan biasa maupun pecahan desimal ke pecahan biasa masih kurang.; e) Kemampuan siswa dalam menyelesaiakan soal cerita yang tipenya penalaran maupun pemecahan masalah masih kurang; f) Kurangnya Reinforcement (penguatan kembali) rumus yang diajarkan oleh guru kepada siswa.

Melalui PhET Simulation, kesulitan-kesulitan siswa tersebut dapat dihindari karena siswa yang akan bereksplorasi untuk menemukan sendiri konsep dari materi tersebut (learning by doing). Pembelajaran berbasis eksplorasi inilah yang secara tidak langsung menuntun siswa untuk berfikir kreatif. Siswa tidak terpaku pada rumus yang diberikan oleh guru dan dapat menemukan sendiri strategi penyelesaian masalah yang bervariasi. Adapun kelebihan lainnya yaitu menghindari siswa dari verbalisme. Artinya, siswa dapat memahami dan mengerti makna yang terkandung dalam penyelesaian masalah yang mereka kerjakan, bukan hanya mengucapkan melalui kata-kata tanpa mengerti maknanya.

Akan tetapi, kenyataan yang terjadi dilapangan memperlihatkan bahwa tujuan pembelajaran tidak akan tercapai apabila proses pembelajaran itu tidak menarik bagi siswa. Apabila guru menginginkan siswa untuk berfikir kreatif, maka terlebih dahulu siswa harus diberikan stimulus, tujuannya adalah membuat sesuatu yang menantang siswa untuk berfikir. Maka, salah satu upaya yang bisa diterapkan oleh guru adalah merancang pembelajaran melalui game edukasi.

Menurut Budianto dalam (Prasetiyo, H., Widaningrum, I., \& Astuti, 2020) lingkungan belajar yang menarik dan menyenangkan dapat mempermudah siswa dalam memahami materi pembelajaran. Game dapat dimanfaatkan untuk menciptakan lingkungan belajar yang demikian dan menghilangkan kejenuhan. Selain itu, Molina dalam (Prasetiyo, H., Widaningrum, I., \& Astuti, 2020)mendefinisikan bahwa game edukasi sebagai sebuah bentuk permainan yang dirancang sedemikian rupa sehingga memiliki unsur nilai-nilai pendidikan. Dimana, tujuan dari game edukasi ini adalah merangsang daya pikir, meningkatkan konsentrasi, dan melatih siswa memecahkan masalah dengan strategi yang bervariasi.

Salah satu game edukasi yang berkembang saat ini adalah dengan menggunakan aplikasi smartphone berbasis android. Menurut Rifai dalam (Prasetiyo, H., Widaningrum, I., \& Astuti, 2020)saat 
ini pengguna android di Indonesia meningkat 22\%. Hal ini dikarenakan berbagai kelebihan yang diberikan android kepada penggunanya, diantaranya menyediakan platform terbuka, interaktivitas, user experience, dan kemudahan pada aplikasinya.

Berbagai kelebihan pada android ini dapat dimanfaatkan untuk membuat game edukasi berbasis smartphone, misalnya dengan Software Construct 2. Menurut Hartanto dalam (Herawati, A., Wahyudi, W., \& Indarini, 2018) Software Construct 2 merupakan salah satu perangkat lunak yang dapat menghasilkan aplikasi atau game (game engine). Pemilihan Software Construct 2 memiliki alasan karena mudah memahami sebuah materi jika disampaikan dengan menarik dan unik serta tidak memerlukan pemprograman yang rumit untuk membuatnya.

Adapun beberapa penelitian relevan tentang pengembangan media pembelajaran game edukasi ini. Misalnya, penelitian yang dilakukan oleh Saputro, T. A., Kriswandani, K., \& Ratu (2018)dengan judul Pengembangan Media Pembelajaran Menggunakan Aplikasi Construct 2 pada Materi Aljabar Kelas VII. Dari hasil penelitiannya, diperoleh kesimpulan bahwa media pembelajaran ini berpengaruh terhadap peningkatan hasil belajar siswa. Selanjutnya, penelitian yang dilakukan oleh Farid, A. M., Faradiyah, A. R., Maghfira, A., Lestari, A. P., \& Tullah, (2018) dengan judul Pengaruh Media Simulasi PhET Menggunakan Model Discovery Learning Terhadap Hasil Belajar Fisika Peserta Didik. Dari hasil penelitiannya, diperoleh kesimpulan bahwa kelompok eksperimen yang diajarkan menggunakan $P h E T$ Simulatian menunjukkan peningkatan hasil belajar yang lebih baik daripada kelompok kontrol.

Berdasarkan penelitian tersebut terlihat bahwa media pembelajaran Software Construct 2 dan PhET Simulation dapat meningkatkan hasil belajar siswa. Namun, penelitian tersebut masih memiliki batasan, yaitu (1) Media pembelajaran yang dikembangkan masih menggunakan laboratorium komputer yang ada di sekolah sehingga kurang fleksibel dan efisien; (2) Media pembelajaran tersebut terbatas pada materi fisika, (3) Media pembelajaran tersebut hanya terfokus pada hasil belajar siswa; (4) Kedua media pembelajaran tersebut tidak terkait satu sama lainnya, padahal Software Construct 2 dapat di link ke PhET Simulation.

Dari batasan penelitian tersebut, maka peneliti ingin mengembangkan sebuah media pembelajaran matematika yang dirancang dengan konsep game edukasi berbasis smartphone yang dikembangkan menggunakan Software Construct 2, dimana didalam proses pembelajaran tersebut akan dibantu PhET Simulation untuk mengarahkan siswa berfikir kreatif. Dikarenakan game edukasi ini dirancang menggunakan model pembelajaran Instructional Games, maka siswa dapat belajar sambil bermain melalui ekplorasi mandiri dalam pembelajaran di kelas. Artinya, siswa tidak menyadari bahwa ketika mereka sedang bermain sebenarnya mereka sedang belajar.

Berdasarkan latar belakang tersebut, peneliti bermaksud melakukan sebuah penelitian pengembangan di SMP Negeri 8 Muaro Jambi. Karena berdasarkan hasil obervasi dan wawancara yang peneliti lakukan di SMP tersebut, diperoleh informasi bahwa hampir semua siswa memiliki smartphone, tersedianya fasilitas infokus, dan adanya jaringan internet WIFI yang dapat dimanfaatkan pada saat proses pembelajaran. Namun dalam pembelajaran matematika, semua fasilitas tersebut tidak 
dimanfaatkan secara maksimal. Sumber belajar yang digunakan guru hanya berupa buku paket dan tanpa menggunakan media pembelajaran. Metode pembelajaranpun juga masih menerapkan metode pembelajaran konvensional, yaitu metode ceramah. Maka dari itu, dengan adanya media pembelajaran yang peneliti kembangkan ini, diharapkan menjadi salah satu media pembelajaran matematika yang menyenangkan dan dapat meningkatan kemampuan berfikir kreatif siswa dalam proses pembelajaran. Berdasarkan uraian di atas, penulis tertarik untuk melakukan penelitian yang berjudul "Pengembangan Game Edukasi Menggunakan Software Construct 2 Berbantuan PhET Simulation Berorientasi pada Kemampuan Berfikir Kreatif Siswa"

\section{METODE}

Penelitian ini termasuk dalam jenis penelitian dan pengembangan atau Research and Design (R\&D). Menurut Sugiyono (2016) metode penelitian dan pengembangan atau dalam bahasa inggrisnya Research and Development adalah metode penelitian yang digunakan untuk menghasilkan produk tertentu, dan menguji keefektifan produk tersebut.

Adapun model pengembangan yang digunakan dalam penelitian ini adalah model pengembangan ADDIE. Dalam bukunya yang berjudul Instructional Design: The ADDIE Approach, Branch (2009) menyatakan "ADDIE is an acronym for Analyze, Design, Develop, Implement, and Evaluate. ADDIE is a product development concept. The ADDIE concept is being applied here for constructing performance-based learning". Dalam bahasa Indonesia berarti "ADDIE adalah singkatan dari menganalisis, merancang, mengembangkan, melaksanakan, dan mengevaluasi. Adapun langkahlangkah pengembangan media pembelajaran dengan model ADDIE menurut Branch (2009) ditunjukkan dalam Gambar 1 berikut:

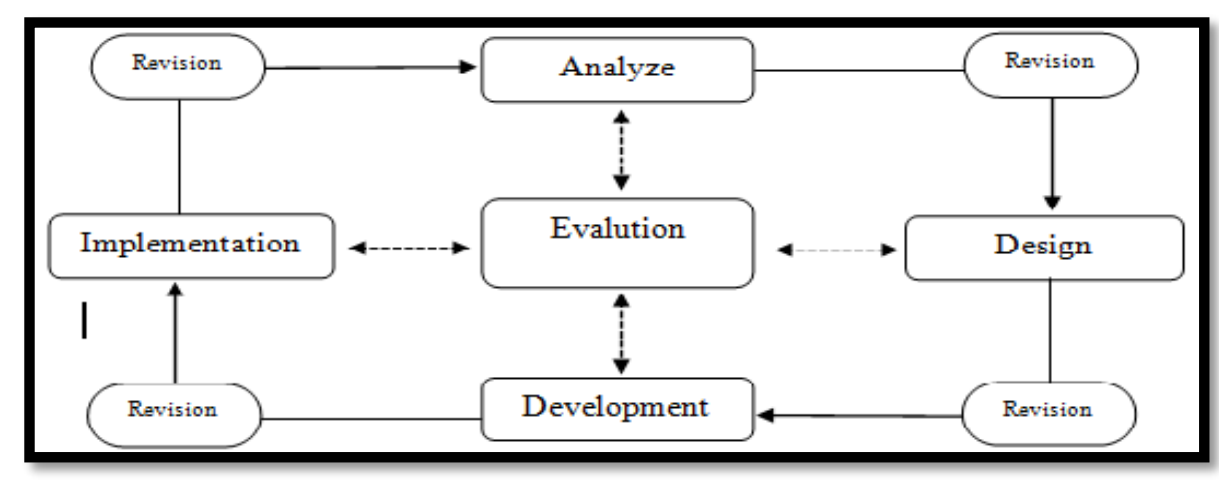

Gambar 1. Model Pengembangan ADDIE (Branch, 2009)

Secara rinci prosedur pengembangan pada penelitian ini dapat dilihat pada Gambar 2 berikut: 


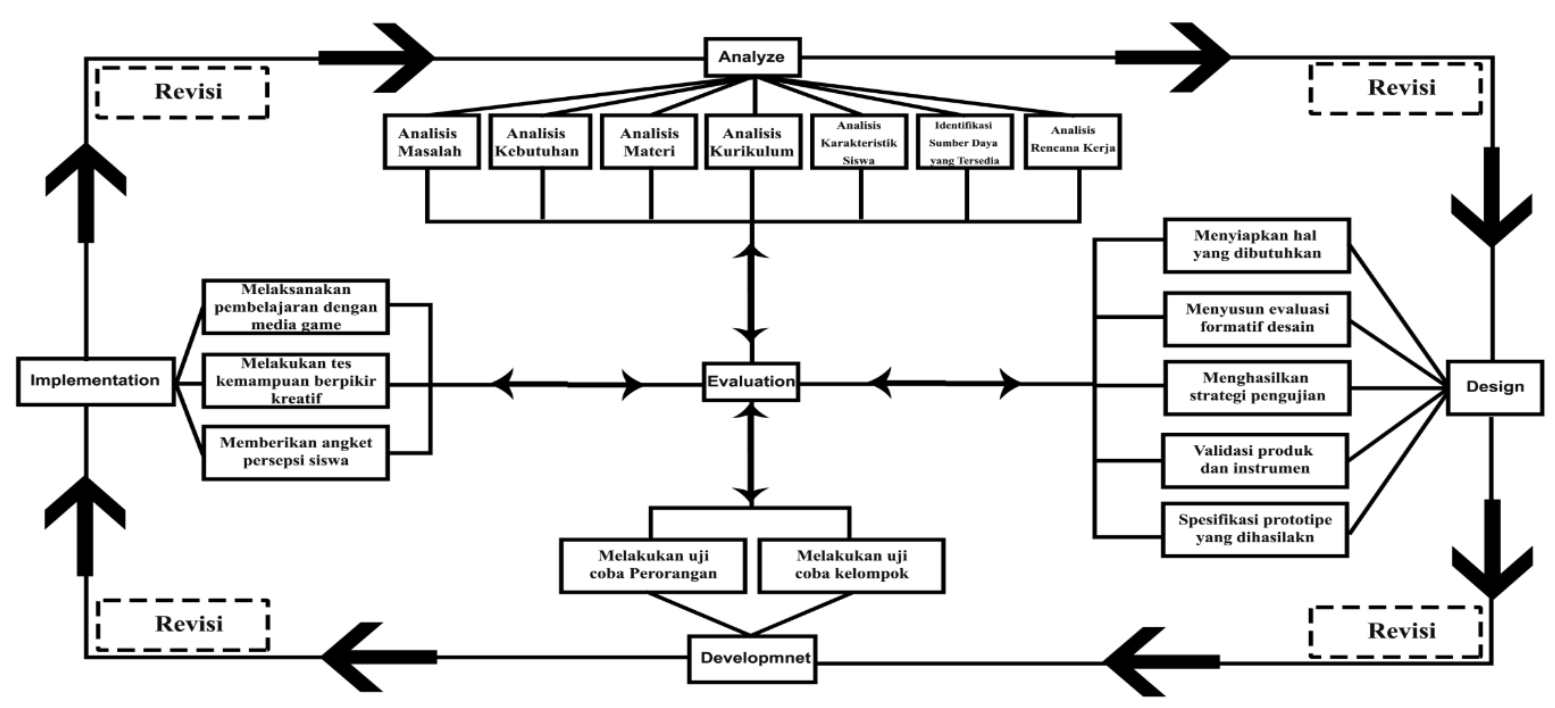

Gambar 2. Diagram Prosedur Pengembangan Penelitian

Subjek ujicoba penelitian ini adalah siswa kelas VII SMPN 11 Kota Jambi Tahun Pelajaran 2021/2022. Instrumen yang digunakan pada penelitian ini terbagi menjadi instrument kevalidan yaitu lembar validasi, kepraktisan berupa lembar angket penilaian guru dan lembar angket penilaian siswa, serta instrument untuk menguji keefektivan berupa soal kemampuan berpikir kreatif dan lembar angket persepsi siswa.

\section{HASIL DAN DISKUSI}

\section{Hasil}

Hasil proses pengembangan media pembelajaran game edukasi menggunakan Software Construct 2 berbantuan Phet Simulation menggunakan model pengembangan ADDIE sebagai berikut.

\section{Analyze (Analisis)}

Tahapan ini terdiri dari analisis masalah, analisis kebutuhan, analisis materi, analisis karakteristik siswa, identifikasi sumber daya yang tersedia, serta analisis rencana kerja. Analisis masalah dilakukan dengan mewawancarai siswa kelas VII SMP Negeri 8 Muaro Jambi secara acak. Berdasarkan hasil wawancara ditemukan informasi bahwa salah satu faktor yang menjadi masalah yaitu belum adanya media khusus yang dapat membantu meningkatkan proses berpikir kreatif siswa. Selain itu juga, dari hasil wawancara didapatkan data bahwa rata-rata siswa sangat senang bermain game bergenre petualangan yang disediakan pada perangkat smartphone mereka atau mereka dapat mengunduh gratis pada layanan google playstore. Melihat hal tersebut, akan menjadi peluang yang baik jika kita menyediakan game petualangan pada smartphone dimana pada game tersebut memuat proses pembelajaran dan hiburan, terkhusus lagi game tersebut dapat menumbuhkembangkan proses berpikir kreatifnya.

Pada analisis kebutuhan dilakukan untuk menemukan apa yang dibutuhkan dari kondisi permasalahan yang ada pada pembelajaran matematika kelas VII SMP. Dari hasil pengamatan dan 
wawancara terkait pembelajaran yang dibuat oleh guru berkaitan dengan perangkat pembelajaran yang digunakan, pembuatan perangkat pembelajaran yang berupa RPP masih mengadopsi dari hasil pelatihan guru. Bahan ajar yang digunakan guru adalah buku kurikulum 2013 serta LKS dari penerbit dengan cakupan materinya kurang mendalam. Kemudian guru masih enggan membuat media pembelajaran yang berupa media edukasi yang sifatnya elektronik atau media interaktif. Selain itu juga perangkat pembelajaran yang mendukung kemampuan berpikir kreatif juga masih belum mendukung.

Berdasarkan temuan diatas dan dari analisis masalah yang telah dijelaskan, maka pengembangan media game edukasi sangat diperlukan agar tercapainya proses pembelajaran yang maksimal bagi siswa maupun guru. Pengembangan media game edukasi ini diharapkan akan menunjang kemampuan berpikir kreatif matematika siswa. Selain itu, untuk merancang sebuah game edukasi yang sesuai dengan keadaan lapangan maka dibutuhkan hal-hal berikut ini:

1. Game edukasi yang dikembangkan harus menarik dengan tampilan yang berwarna dan memiliki interface yang modern.

2. Game edukasi yang dikembangkan bisa dimainkan secara offline maupun online.

3. Game edukasi yang dikembangkan harus dapat dijalankan dengan perangkat android dengan spesifikasi minimum.

4. Game edukasi yang dikembangkan harus memiliki versi mobile dan PC, sehingga ketika pada saat penelitian siswa yang tidak memiliki smartphone yang memadai dapat menggunakan perangkat PC dalam memainkannya.

5. Game edukasi yang dikembangkan harus memiliki navigasi yang sederhana dan mudah dipahami dalam penggunaanya.

Hasil analisis materi diperoleh bahwa materi yang akan digunakan dalam pengembangan ini yaitu materi Bilangan Kelas VII SMP. Hal ini dikarenakan pada materi ini menunutut siswa untuk dapat berpikir kreatif dalam penyelesaiannya. Selain itu juga, untuk mengerjakan soal-soal pada materi Bilangan Kelas VII SMP siswa dapat menyelesaikannya bukan dengan satu cara saja, melainkan dengan berbagai cara. Analisis materi juga dilakukan dengan menyesuaikan kurikulum 2013 yang digunakan di SMP Negeri 8 Muaro Jambi.

Analisis karakteristik siswa dilakukan dengan mendiskusikan karaktersitik subjek penelitian bersama guru yang mengajar kelas VII SMP Negeri 8 Muaro Jambi. Siswa yang menjadi subjek penelitian adalah siswa SMP Negeri 8 Muaro Jambi kelas VII F yang memiliki usia kisaran 12-13 tahun. Menurut guru yang mengajar matematika kelas VII F siswa memiliki tingkat rasa ingin tahu masih sangat tinggi yang diimbagi kebutuhan untuk bermain, sehingga kelas VII F dipilih sebagai subjek penelitian.

Hasil wawancara dengan subjek penelitian didapati bahwa setiap hari mereka selalu memainkan game smartphone. Rata-rata siswa menghabiskan 2-3 jam setiap harinya untuk bermain game pada smartphone, dan beberapa siswa mengatakan bahwa mereka sering dimarahi oleh orang tuanya karena terlena dalam bermain game dan lupa untuk belajar. Berdasarkan kedua hal diatas maka game edukasi 
Pengembangan Game Edukasi Menggunakan Software Construct 2 Berbantuan Phet Simulation Berorientasi pada Kemampuan Berpikir Kreatif Siswa, Debby Arisandy, Jefri Marzal, Maison

yang dikembangkan dapat memfasilitasi keinginan siswa untuk bermian game dan kegiatan belajar. Game edukasi yang dikembangkan dapat menjadikan aktivitas siswa sebagai bermain sambil belajar sesuai dengan karakterisik berbasis edukasi. Identifikasi sumber daya dilakukan dengan melakukan pendataan pada fasilitas teknologi informasi dan komunikasi berupa Smartphone yang dimiliki siswa kelas VII SMP Negeri 8 Muaro Jambi. Identifikasi sumber daya yang tersedia disajikan dalam bentuk tabel hasil dari survei sebagai berikut.

Tabel 1. Hasil Identifikasi Sumber Daya yang Tersedia

\begin{tabular}{|c|c|c|c|}
\hline \multirow{2}{*}{ No } & \multirow{2}{*}{ Frekuensi Siswa } & \multicolumn{2}{|c|}{ Smartphone } \\
\cline { 3 - 4 } & & Jenis Smartphone & Tipe Android \\
\hline 1 & 5 Siswa & Asus & OS Android V4.4.2 Kitkat \\
\hline 2 & 3 Siswa & Evercross & OS Android Gingerbread \\
\hline 3 & 8 Siswa & Xiaomi & OS Android Lollipon 5.0 2.3.3 \\
\hline 4 & 7 Siswa & Mito & OS Android Gingerbread \\
\hline 5 & 3 Siswa & Samsung & OS Android V4.4.2 Kitkat \\
\hline 6 & 4 Siswa & Oppo & OS Android V4.4.2 Kitka \\
\hline
\end{tabular}

Berdasarkan hasil pada tabel 1 diketahui bahwa semua siswa memiliki perangkat android. Selain itu dilihat dari jenis tipe androidnya, semua perangkat hanya memiliki tipe android menengah kebawah sehingga dapat disimpulkan bahwa pada saat perancangan game edukasi harus dapat dimainkan pada OS Android tipe minimum, dalam kata lain semua tipe smartphone akan dapat memainkan game yang dirancang. Analisis rencana kerja dilakukan dengan merancang jadwal, tim, dan spesifikasi media.

\section{Design}

\section{Menyiapkan Hal yang Dibutuhkan}

Semua mulai di realisasikan untuk menghasilkan sebuah produk yang dapat digunakan dalam kegiatan pembelajaran:

\section{Flowchart Rancangan Game Edukasi}

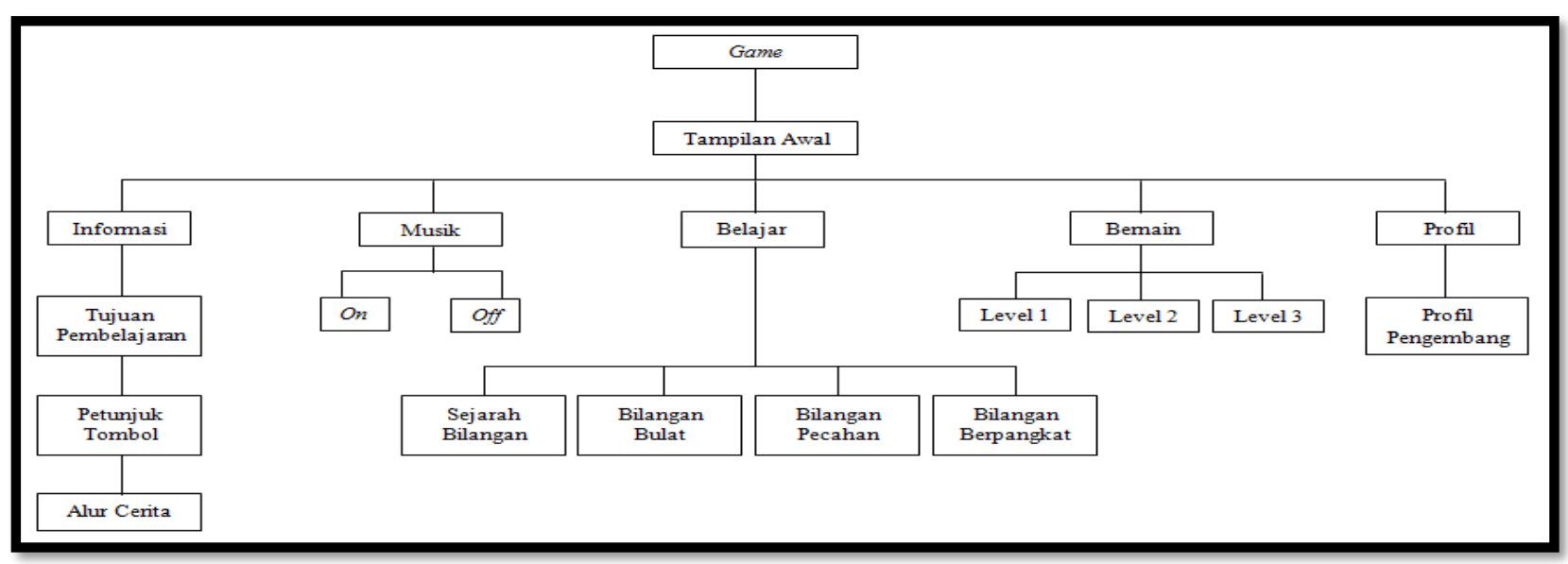

Gambar 3. Rencana Desain Game Edukasi

Rencana desain game edukasi pada Gambar 3. dibuat berdasarkan alur proses permainan didalam game yang nantinya diaplikasikan pada saat membuat game edukasi dengan Software 
Construct 2 berbantuan PhET Simulation. Antar muka dirancang lebih menarik untuk menjawab kebutuhan siswa yang mengingkan game edukasi yang memiliki tampilan yang menarik.

2. Membuat Story Board

Rancangan media pembelajaran game edukasi berbasis smartphone berorientasi pada kemampuan berpikir kreatif siswa dalam story board pada tabel 2 dibawah ini.

Tabel 2. StoryBoard Perancangan Game edukasi

\begin{tabular}{|c|c|c|}
\hline No. & Visual & Keterangan \\
\hline (1) & (2) & (3) \\
\hline 1 & Tampilan Awal Media Pembelajaran & $\begin{array}{l}\text { Nama game edukasi ini adalah Petualangan Bila. } \\
\text { Pada tampilan awal akan terlihat karakter pemain } \\
\text { yang bernama BILA, yang merupakan singkatan dari } \\
\text { kata Bilangan. } \\
\text { Ada enam tombol yang dapat di klik, yaitu: } \\
\text { 1. A: Informasi } \\
\text { 2. B: Exit } \\
\text { 3. C: On / Off music } \\
\text { 4. D: Informasi pengembang media } \\
\text { 5. Menu Belajar } \\
\text { 6. Menu Bermain }\end{array}$ \\
\hline 2 & Tampilan Awal Menu Belajar & $\begin{array}{l}\text { Pada menu belajar berisi materi Bilangan Kelas VII } \\
\text { SMP. Materi ini terbagi lagi menjadi tiga sub materi. } \\
\text { Ada lima tombol yang dapat di klik, yaitu: } \\
\text { 1. B: Exit } \\
\text { 2. E: Kembali ke tampilan awal } \\
\text { 3. H: Materi Bilangan Bulat } \\
\text { 4. I: Materi Bilangan Pecahan } \\
\text { 5. J: Materi Bilangan Berpangkat }\end{array}$ \\
\hline 3 & Tampilan Isi Menu Belajar & $\begin{array}{l}\text { Di dalam menu belajar, selain terdapat materi juga } \\
\text { terdapat beberapa permasalahan yang menuntun } \\
\text { siswa untuk berfikir kreatif. Pada bagian ini guru } \\
\text { juga akan menggunakan PheT Simulation utuk } \\
\text { membantu siswa memahami materi. } \\
\text { Ada empat tombol yang dapat di klik, yaitu: } \\
\text { 1. B: Exit } \\
\text { 2. E: Kembali ke tampilan awal } \\
\text { 3. F: Ke tampilan selanjutnya } \\
\text { 4. G: Ke tampilan sebelumnya } \\
\text { 5. K: Alternatif Penyelesaian }\end{array}$ \\
\hline
\end{tabular}


Pengembangan Game Edukasi Menggunakan Software Construct 2 Berbantuan Phet Simulation Berorientasi pada Kemampuan Berpikir Kreatif Siswa, Debby Arisandy, Jefri Marzal, Maison

\begin{tabular}{|c|c|c|}
\hline 4 & Tampilan Awal Menu Bermain & $\begin{array}{l}\text { Pada menu bermain terbagi menjdi tiga level yang } \\
\text { harus di selesaikan. } \\
\text { Ada lima tombol yang dapat di klik, yaitu: } \\
\text { 1. B: Exit } \\
\text { 2. E: Kembali ke tampilan awal } \\
\text { 3. L: Level } 1 \text { (Bilangan Bulat) } \\
\text { 4. M: Level } 2 \text { (Bilangan Pecahan) } \\
\text { 5. N: Level } 3 \text { (Bilangan } \\
\quad \text { Berpangkat) }\end{array}$ \\
\hline 5 & Tampilan Isi Menu Bermain & 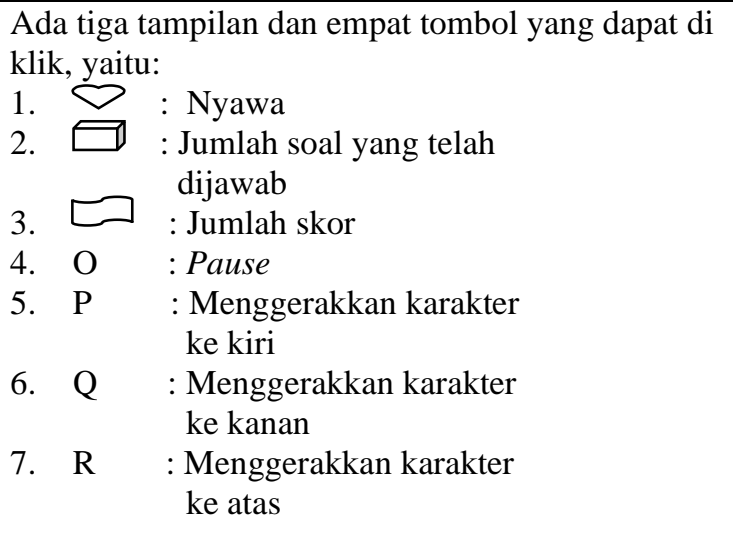 \\
\hline 6 & $\begin{array}{l}\text { Tampilan Jika Berhasil Menjalankan } \\
\text { Misi Game }\end{array}$ & $\begin{array}{l}\text { Pemain dapat melanjutkan ke level berikutnya jika } \\
\text { mencapai skor minimum } 75 \text {. Adapun ketentuan } \\
\text { penskorannya yaitu sebagai berikut: } \\
\text { - Mengambil bilangan: }+1 \\
\text { - } \quad \text { Membunuh musuh: }+2 \\
\text { - } \quad \text { Berhasil menjawab soal: }+10 \\
\text { Ada tiga tombol yang dapat di klik, yaitu: } \\
\text { 1. E: Kembali ke tampilan awal } \\
\text { 2. S: Mengulang permainan } \\
\text { 3. T: Melanjutkan ke level } \\
\text { berikutnya }\end{array}$ \\
\hline 7 & $\begin{array}{l}\text { Tampilan Jika Gagal Menjalankan } \\
\text { Misi }\end{array}$ & $\begin{array}{l}\text { Pemain tidak dapat melanjutkan ke level berikutnya } \\
\text { jika memperoleh skor dibawah } 75 \text {. Jika hal itu } \\
\text { terjadi, maka akan muncul tampilan seperti gambar } \\
\text { disamping. Pemain harus mengulang misi game } \\
\text { tersebut dari awal. } \\
\text { Ada dua tombol yang dapat di klik, yaitu: } \\
\text { 1. E: Kembali ke tampilan awal } \\
\text { 2. S: Mengulang permainan }\end{array}$ \\
\hline
\end{tabular}

\section{Validasi Produk dan Instrumen}

Validasi produk dilakukan melalui validasi oleh ahli media dan ahli materi. Penilaian media dilakukan oleh 1 orang dosen pascasarjana UNJA dengan menganalisis media berdasarkan aspek aspek 
yang ditentukan dan diberikan dalam bentuk angket validasi media Dari hasil pengisian angket oleh validator media dapat disimpulkan bahwa media yang dikembangkan telah memenuhi validitas konstruk sedangkan untuk validitas isinya dilihat dari penilaian ahli materi. Berdasarkan hasil validasi ahli media pembelajaran maka game edukasi ini dinyatakan valid dan layak untuk diujicobakan dilapangan setelah melalui beberapa revisi salah satunya menambahkan alur cerita pada bagian informasi. Alur Alur cerita ini berisi deskrispsi singkat cara bermain agar pemain lebih mudah menjalankan misi dalam game tersebut. Adapun komentar dan hasil revisi pada produk dapat dilihat pada gambar 4 dan 5 berikut.

\section{Kemudahan memakai.}

Komentar dan saran perbaikan:

Dalam hal ini sangat relatif karena banyak faktor untuk menyatakan kemudahan memakainya. Misalnya siswa yang masih awan bermain game tentu akan sulit beradaptasi.

Saran : Sebaiknya pada informasi selain tujuan permainan ditambah dengan Deskripsi singkat cara bermain.

Gambar 4. Saran Perbaikan dari Ahli Media agar Menambahkan Alur Cerita

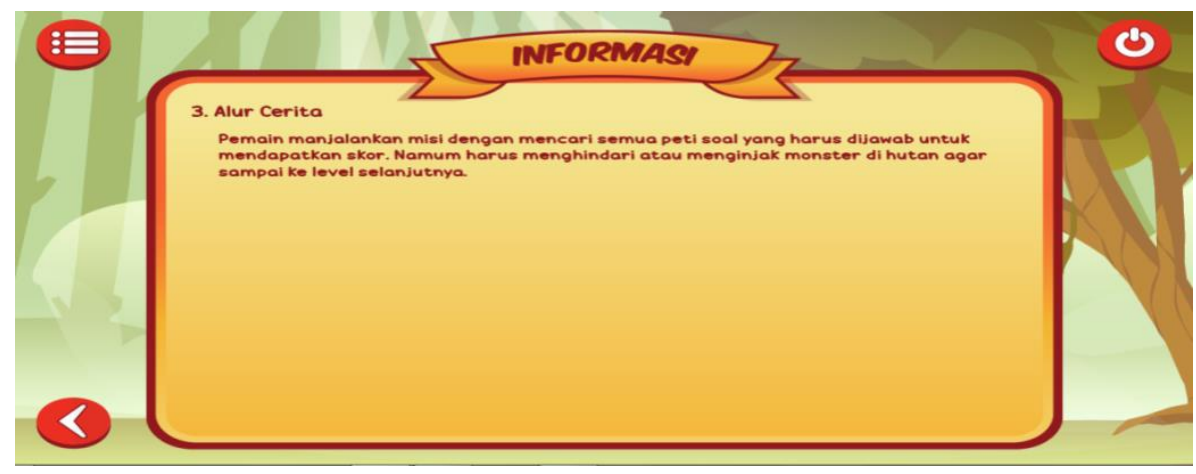

Gambar 5. Hasil Revisi dari Ahli Media agar Menambahkan Alur Cerita

Penilaian materi yang digunakan pada media dilakukan oleh 1 orang dosen pascasarjana UNJA dengan menganalisis media berdasarkan aspek aspek yang ditentukan dan diberikan dalam bentuk angket validasi materi hasil pengisian angket oleh validator materi dapat disimpulkan bahwa media yang dikembangkan telah memenuhi validitas isi. Maka media game edukasi ini termasuk dalam kategori "valid" dari segi materi yang digunakan setelah melalui revisi seperti memperbaiki bahasa penulisan

Berdasarkan penilaian ahli media dan ahli materi, maka dapat disimpulkan bahwa media telah memenuhi kriteria valid setelah melalui beberapa revisi. Kevalidan dari produk yang dikembangkan ini didasarkan pada pendapat Nienke Nieveen (1999) yang menyatakan bahwa sebuah produk atau media dikatakan valid yaitu dengan melihat keterkaitannya, serta mempertimbangkan tujuan dari pengembangan produk tersebut, dimana kriteria kevalidan mencakup validitas isi yaitu kesesuaian komponen-komponen yang melandasi pembuatan produk, dan validitas konstruk yaitu keterkaitan seluruh komponen dalam pengembangan produk. 
Pengembangan Game Edukasi Menggunakan Software Construct 2 Berbantuan Phet Simulation Berorientasi pada Kemampuan Berpikir Kreatif Siswa, Debby Arisandy, Jefri Marzal, Maison

\section{Development}

Pada tahap ini peneliti melakukan ujicoba terbatas sebelum ketahap implementasi. Uji coba yang dilakukan yaitu uji coba perorangan dan ujicoba kelompok kecil.

\section{Uji Coba Kelompok Kecil}

Uji Coba perorangan dilakukan oleh guru matematika untuk menilai media pembelajaran tahap awal. Guru yang memberikan penilaian terdiri dari satu orang guru matematika yang mengajar di kelas VII SMP Negeri 8 Muaro Jambi. Adapun hasil dari pengisian angket penilaian guru dapat dilihat pada lampiran 6. Dari ujicoba perorangan didapatkan hasil bahwa produk yang digunakan memenuhi kriteria kepraktisan dengan rata-rata 3,78.

\section{Uji Coba Kelompok Kecil}

Pada tahap ujicoba kelompok kecil subjek ujicoba yang dipilih peniliti adalah 8 orang dari kelas VII B dimana siswa ini berkemampuan rendah, sedang, dan tinggi. Pemilihan siswa yang menjadi subjek ujicoba kelompok kecil di bantu oleh guru matematika yang mengajar dikelas tersebut yang telah mengetahui kemampuan matematika siswa di kelas VII B. Dari ujicoba kelompok kecil didapatkan hasil bahwa produk dinyatakan praktis dengan rata-rata 4,12.

\section{Uji Coba Kelompok Besar}

Pada tahap ujicoba kelompok besar subjek ujicoba yang dipilih peniliti adalah 30 orang dari kelas VII E dimana siswa ini berkemampuan rendah, sedang, dan tinggi. Pemilihan siswa yang menjadi subjek ujicoba kelompok besar di bantu oleh guru matematika yang mengajar dikelas tersebut yang telah mengetahui kemampuan matematika siswa di kelas VII E. Berdasarkan hasil penyebaran lembar angket diperoleh bahwa produk dinyatakan praktis dengan rata-rata 4,15.

\section{Implementation}

Pada tahap implementasi produk yang telah diujicoba diterapkan dalam situasi nyata dengan pengajaran yang sesungguhnya menggunakan game edukasi yang melibatkan subjek 30 atau satu kelas yaitu kelas VII F SMP Negeri 8 Muaro Jambi. Kegiatan pembelajaran dilaksanakan selama 7 x pertemuan. Pada tahap implementasi dilakukan pretest dan postest untuk melihat peningkatan kemampuan berpikir kreatif siswa. Berdasarkan hasil tes diperoleh hasil uji N-gain sebesar 0,67 dengan kriteria peningkatan sedang.

\section{Evaluation}

Pada tahapan ini dilakukan evaluasi yang bertujuan untuk memperbaiki produk yang dikembangkan. Tahap evaluasi dilakukan pada akhir setiap langkah sebelumnya. Evalusi dilakukan pertama kali dengan cara berkonsultasi dengandosen pembimbing. Berdasarkan hasil bimbingan dilakukan beberapa perbaikan sesuai saran yang diberikan.

Evaluasi juga dilakukan pada saat ujicoba terbatas (awal) dimana saran perbaikan didapat peneliti dari angket penilaian guru dan angket penilaian siswa yang diberikan selama proses ujicoba terbatas dilakukan. Tahapan evaluasi juga mencakup penilaian kelayakan dari produk setelah dilakukan implementasi di kelas yang di tinjau dari aspek kepraktisan dan keefektifan. Penilaian terhadap produk 
ditinjau dari aspek kepraktisan dilakukan oleh guru matematika kelas VII dan siswa kelas implementasi dilakukan. Sedangkan evaluasi keefektifan ditinjau dari nilai hasil tes berpikir kreatif dan angket persepsi siswa setelah menggunakan produk yang dikembangkan.

\section{Diskusi}

Berdasarkan data yang diperoleh dari angket validasi media dan materi dapat disimpulkan produk yang dikembangkan valid dan layak digunakan dikarenakan telah sesuai dengan indikatorindikator evaluasi kevalidan suatu media. Hal ini sesuai dengan pendapat yang dikemukakan oleh Plomp, T., \& Nieveen (2007) dimana produk dikatakan valid jika produk yang dikembangkan berdasarkan rasional teoritik yang kuat dan terdapat konsistensi internal antara komponen- komponen produk yang dikembangkan.

Praktikalitas merupakan tingkat keterpakaian atau kemudahan media untuk digunakan oleh peserta didik. Analisis kepraktisan didapat dari penilaian guru dan penilaian siswa terhadap media yang dikembangkan. Terdapat 3 aspek yang diukur pada penilaian guru dan 2 aspek pada penilaian siswa. Pada penilaian guru ketiga aspek yang diukur tersebut adalah aspek menarik, aspek mudah digunakan dan aspek kualitas isi. Berdasarkan hasil penilaian guru, diperoleh rata-rata ketiga aspek yaitu 3,78 dengan secara kualitatif adalah praktis $(3,4 \leq \mathrm{x} \leq 4,2)$. Dimana rata-rata aspek menarik adalah 4 dengan klasifikasi baik $(3,4 \leq \mathrm{x} \leq 4,2)$. Rata-rata mudah digunakan adalah 3,67 dengan klasifikasi secara kualitatif adalah baik $(3,4 \leq \mathrm{x} \leq 4,2)$. Rata-rata skor kualitas isi adalah 3,63 dengan kualifikasi secara kualitatif adalah baik $(3,4 \leq \mathrm{x} \leq 4,2)$. Rata-rata indikator berfikir kreatif adalah 3,83 dengan kualifikasi secara kualitatif adalah baik $(3,4 \leq \mathrm{x} \leq 4,2)$. Dengan demikian berdasarkan hasil angket penilaian guru dapat disimpulkan bahwa media game edukasi menggunakan Software Construct 2 Berbantuan PhET Simulation yang berorientasi pada kemampuan berpikir kreatif siswa memenuhi kriteria "Praktis" untuk digunakan.

Pada penilaian siswa, kedua aspek yang diukur adalah aspek menarik dan mudah digunakan. Berdasarkan hasil penilaian siswa dari ujicoba kelompok kecil, diperoleh rata-rata kedua aspek adalah 4,12 dengan kualifikasi secara kualitatif adalah baik $(3,4 \leq x \leq 4,2)$. Dimana rata-rata aspek skor menarik adalah 4,25 dengan kualifikasi secara kualitatif adalah sangat baik $(\mathrm{x} \leq 4,2)$. Rata-rata aspek mudah digunakan adalah 3,98 dengan klasifikasi secara kualitatif adalah baik $(3,4 \leq \mathrm{x} \leq 4,2)$. Dengan demikian berdasarkan hasil angket penilain siswa dapat disimpulkan bahwa media game edukasi menggunakan Software Construct 2 Berbantuan PhET Simulation memenuhi kriteria "Praktis" untuk digunakan.

Keefektifan media game edukasi pada penelitian ini dilihat dari peningkatan tes kemampuan berpikir kreatif dan persepsi siswa. Berdasarkan hasil implementasi dilapangan, media media game edukasi menggunakan Software Construct 2 Berbantuan PhET Simulation telah memenuhi kriteri efektif. Dari hasil uji gain untuk melihat peningkatan kemampuan berpikir kreatif diperoleh skor kenaikan sebesar 0,67. Sehingga dapat disimpulkan bahwa game edukasi ini efektif karena dapat meningkatkan kemampuan berpikir kreatif siswa dengan kriteria peningkatan sedang.Media game edukasi menggunakan Software Construct 2 Berbantuan PhET Simulation yang berorientasi pada 
kemampuan berpikir kreatif siswa sudah dapat dikatakan "efektif" untuk digunakan dalam proses pembelajaran. Hal ini sesuai dengan pendapat Nienke Nieveen (1999) yang menyatakan bahwa keefektifan produk pengembangan dilihat dari konsistensi antara rancangan atau tujuan dengan pengalaman dan hasil belajar yang dicapai siswa. Pengalaman siswa ditentukan melalui persepsi siswa terhadap media, selanjutnya hasil belajar ditentukan melalui hasil tes. Penelitian Ardani, R. A., Salsabila, N. H., Handican, R., \& Setyaningrum (2018) juga melakukan uji keefektifan. Data yang diambil adalah data tes kemampuan pemahaman konsep dan angket minat belajar siswa. Namun didalam penelitiannya, untuk tes kemampuan pemahaman konsepnya diukur dengan mengguanakan soal berbentuk pilihan ganda berbeda dengan bentuk tes yang penulis buat yaitu tes yang berbentuk uraian sehingga terlihat dengan jelas proses menemukan kemampuan berpikir kreatifnya.

\section{KESIMPULAN}

Penelitian pengembangan ini telah menghasilkan suatu produk berupa Media Pembelajaran Game Edukasi Menggunakan Software Construct 2 Berbasis PhET Simulation Berorientasi pada Kemampuan Berfikir Kreatif Siswa. Media game edukasi yang dikembangkan dalam penelitian ini memenuhi kualitas media yang valid, praktis, dan efektif, karena media game edukasi ini sudah dinyatakan memenuhi kriteria kevalidan, yaitu berdasarkan hasil validasi dari ahli desain media, diperoleh kesimpulan bahwa media sudah valid untuk digunakan. Memenuhi kriteria kepraktisan, yaitu berdasarkan hasil penilaian dari seorang guru matematika diperoleh skor rata-rata 3,78, ini termasuk dalam kategori 3,4 $\leq x \leq 4,2$. Yaitu "praktis". Dari hasil penilaian siswa, pada ujicoba kelompok kecil diperoleh rata-rata skor 4,12, ini termasuk dalam kategori $3,4 \leq \mathrm{x} \leq 4,2$. yaitu "praktis". Sedangkan, pada ujicoba kelompok besar diperoleh rata-rata skor 4,15, ini termasuk dalam kategori $3,4 \leq \mathrm{x} \leq 4,2$. yaitu "praktis". Dari dua hal tersebut, maka dapat disimpulkan bahwa media game edukasi menggunakan Software Construct 2 berbasis PhET Simulation berorientasi pada kemampuan berfikir kreatif siswa memenuhi kriteria "praktis". Selain itu, produk yang dihasilkan sudah memenuhi kriteria keefektifan, yaitu berdasarkan hasil tes kemampuan berpikir kreatif siswa didapatkan rata-rata skor pre-test sebesar 10,867 dan ratarata skor post-test sebesar 18,2 dengan peningkatan kemampuan berpikir kreatif siswa sebesar 0,67 yaitu pada kategori peningkatan sedang. Dengan demikian media game edukasi ini dapat meningkatkan kemampuan berpikir kreatif siswa. Dari hasil angket persepsi siswa, diperoleh rata-rata persentase persetujuan tertinggi untuk setiap indikator berada pada kategori setuju.

\section{REFERENSI}

Ardani, R. A., Salsabila, N. H., Handican, R., \& Setyaningrum, W. (2018). The perceptions of students and teachers about the use of edutainment instructional media in mathematics learning. Advances in Social Science, Education and Humanities Research (ASSEHR), 160, 228-234.

Branch, R. (2009). Instructional Design: The ADDIE Approach. Springer: USA.

Farid, A. M., Faradiyah, A. R., Maghfira, A., Lestari, A. P., \& Tullah, H. (2018). Pengaruh media 
simulasi phet (physics education technology) pada mata pelajaran fisika menggunakan model discovery learning terhadap hasil belajar peserta didik. Jurnal Nalar Pendidikan, 6(2), 105-112.

Hanipah, N., Yuliani, A., \& Maya, R. (2018). Analisis Kemampuan berpikir kreatif matematis siswa MTs pada materi lingkaran. AKSIOMA: Jurnal Program Studi Pendidikan Matematika, 7(1), 8086.

Herawati, A., Wahyudi, W., \& Indarini, E. (2018). Pengembangan Media Pembelajaran Bangun Ruang Berbasis Discovery Learning dengan Construct 2 dalam Meningkatkan Kemampuan Pemecahan Masalah Matematika. Jurnal Ilmiah Sekolah Dasar, 2(4), 396-403.

Kemendikbud. (2019). Hasil PISA Indonesia 2018 : Akses Makin Meluas, Saatnya Tingkatkan Kualitas.

Nienke Nieveen. (1999). Prototyping to Reach Product Quality. In In Design Approaches and Tools in Education and Training. Springer.

Plomp, T., \& Nieveen, N. (2007). An introduction to educational design research. In Proceedings of the Seminar Conducted at the East China Normal University, Shanghai (PR China), 23.

Prasetiyo, H., Widaningrum, I., \& Astuti, I. P. (2020). Game Edukasi Math \& Trash Berbasis Android dengan Menggunakan Scirra Construct 2 dan Adobe Phonegap. JURNAL RESTI (Rekayasa Sistem Dan Teknologi Informasi), 4(1), 37-49.

Prastiti, T. D., Tresnaningsih, S., \& Mairing, J. P. (2018). Tingkat kemampuan berpikir kreatif matematis siswa siswa sman di surabaya. AdMathEdu: Jurnal Ilmiah Pendidikan Matematika, Ilmu Matematika Dan Matematika Terapan, 83-94.

Saputro, T. A., Kriswandani, K., \& Ratu, N. (2018). Pengembangan Media Pembelajaran Mengunakan Aplikasi Construct 2 Pada Materi Aljabar Kelas VII. JP2M (Jurnal Pendidikan Dan Pembelajaran Matematika), 4(1), 10-23.

Sugiyono. (2016). Metode Penelitian dan Pengembangan (Research and Development/R\&D). Alfabeta.

Supardi, U. S. (2015). Peran berpikir kreatif dalam proses pembelajaran matematika. Formatif: Jurnal Ilmiah Pendidikan MIPA, 2(3).

Sylviani, S., Permana, F. C., \& Utomo, R. G. (2020). PHET Simulation sebagai Alat Bantu Siswa Sekolah Dasar dalam Proses Belajar Mengajar Mata Pelajar Matematika. Jurnal Pendidikan Multimedia, 2(1), 1-10. Jurnal Pendidikan Multimedia, 2(1), 1-10., 2(1), 1-10.

Utami, L. (2016). Analisis kesulitan siswa SMP kelas VII dalam menyelesaikan soal operasi hitung bilangan dan solusi pemecahannya. 